\title{
A case of azathioprine-related acute pancreatitis and drug-induced acute pancreatitis
}

\author{
Azatiyoprin ilişkili bir akut pankreatit olgusu ve ilaç-ilişkili akut pankreatit
}

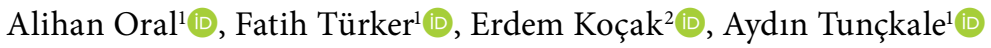 \\ ${ }^{1}$ Department of Internal Medicine, Demiroğlu Bilim University, Faculty of Medicine, İstanbul, Turkey \\ ${ }^{2}$ Department of Internal Medicine, Division of Gastroenterology, Demiroğlu Bilim University, Faculty of Medicine, İstanbul, Turkey
}

\begin{abstract}
Acute pancreatitis (AP) is an inflammatory condition, characterized by elevated levels of amylase and lipase, with manifestation of abdominal pain and acute abdomen, and high mortality and morbidity rates. The most common causes of AP other than gallbladder stones and alcohol include hypercalcemia, infections, hypercalcemia, and drugs. One such drug associated with AP is azathioprine. Azathioprine is used to prevent acute exacerbations in Crohn's disease. Herein, we present a case of azathioprine-related AP in a patient with Crohn's disease.

Keywords: Acute pancreatitis, azathioprine, drug
\end{abstract}

öz

Akut pankreatit (AP), amilaz ve lipaz düzeylerinin yüksekliği ile karakterize, karın ağrısı ve akut batın tablosu izlenen ve mortalite ve morbidite oranları yüksek enflamatuvar bir tablodur. Akut pankreatitin en sık nedenleri arasında safra kesesi taşı ve alkol dışında hiperlipidemi, enfeksiyonlar, hiperkalsemi ve ilaçlar sayılabilir. Akut pankreatit ile ilişkili ilaçlardan biri de azatiopurindir. Azatiopurin, Crohn hastalığında akut alevlenmenin önlenmesinde kullanılmaktadır. Burada Crohn hastalığı olan bir hastada azatiyoprin ile ilişkili bir AP olgusu sunuldu.

Anahtar sözcükler: Akut pankreatit, azatiyoprin, ilaç

Acute pancreatitis (AP) is an inflammatory condition, characterized by elevated levels of amylase and lipase, with manifestation of abdominal pain and acute abdomen, and high mortality and morbidity rates. ${ }^{[1]}$ According to etiology of acute pancreatitis, while gallbladder stones and alcohol are foremost, other causes include hyperlipidemia, infections, hypercalcemia, drug use, and autoimmunity. ${ }^{[2]}$ Drug-induced acute pancreatitis (DIAP) accounts for about $2 \%$ of AP and is generally of mild-moderate severity. ${ }^{[3]}$ Acetaminophen, cortisone, metronidazole, azathioprine (AZT), mercaptopurine, and thiazide are some of the most common drugs that cause AP; drugs associated with AP are presented in Table $1 .^{[3,4]}$ Chron's disease (CD) is a chronic, idiopathic, inflammatory, bowel disease. A purine analogue, AZT, is used in preventing acute exacerbations of Crohn's disease. Acute pancreatitis is also among the adverse effects of AZT. ${ }^{[5]}$ Herein, we present an AP case associated with AZT.

\section{CASE REPORT}

A 28-year-old female patient presented to our emergency department with belt-like abdominal 
Table 1. Drug-induced acute pancreatitis

\begin{tabular}{|c|c|c|c|}
\hline ACE Inhibitor & Cyproheptadine & Linagliptin & Liraglutide \\
\hline Macrolides & Rifapentine & Acetaminophen & Cytosine \\
\hline Mefenamic acid & Rivastigmine & ACTH & Danazol \\
\hline 6-MP & Ropinirole & Alendronate & Dapsone \\
\hline Mesalamine & Saw palmetto & Saxagliptin & All-trans-retinoic acid \\
\hline Alogliptin & DDP-4 inhibitors & Metformin & SSRIs \\
\hline Alpha-methyldopa & Diazoxide & Methimazole & Sirolimus \\
\hline Sitagliptin & Aminosalicylates & Diphenoxylate & Methyldopa \\
\hline Sodium stibogluconate & Amiodarone & Dipyridamole & Divalproex sodium \\
\hline Metronidazole & Somatropin & Amlodipine & Doxercalciferol \\
\hline Mirtazapine & Statins & Ampicillin & Doxorubicin \\
\hline Montelukast & Sulfamethoxazole & Antivirals & Ertapenem \\
\hline Mycophenolate & Sulfasalazine & Aspirin & Estrogens \\
\hline Exenatide & Nitrofurantoin & Sumatriptan & Atypical antipsychotics \\
\hline Fibrates & NSAIDs & Tacrolimus & Azathioprine \\
\hline Finasteride & Octreotide & Tamoxifen & Bupropion \\
\hline Fluoroquinolones & Paclitaxel & Tetracyclines & Calcitriol \\
\hline 5-Fluorouracil & Pegaspargase & Thiazide diuretics & Cannabis \\
\hline Furosemide & Penicillin & Thrombolytic agents & Capecitabine \\
\hline Gabapentin & Pentamidine & TNF-alpha inhibitors & Carbamazepine \\
\hline GLP-1 analogs & Pergolide & Topiramate & Ceftriaxone \\
\hline Gold & Phenolphthalein & Valproic acid & Cimetidine \\
\hline HAART agents & Pilocarpine & Venlafaxine & Cisplatin \\
\hline Ifosfamide & Prazosin & Vincristine & Clomiphene \\
\hline Indomethacin & Procainamide & Voriconazole & Codeine \\
\hline Interferon/ribavirin & Propofol & Zolmitriptan & Colchicine \\
\hline Interleukin-2 & Propoxyphene & Corticosteroids & Irbesartan \\
\hline PPIs & Co-trimoxazole & Isoniazid & Quinupristin/dalfopristin \\
\hline COX-2 inhibitors & Isotretinoin & Ranitidine & Cyclophosphamide \\
\hline Lamotrigine & Repaglinide & Cyclosporine & L-asparaginase \\
\hline
\end{tabular}

ACE: Angiotensin-converting enzyme; ACTH: Adrenocorticotropic hormone; Rifampin 6-MP: 6-mercaptopurine; DDP-4: Dipeptidyl peptidase 4; SSRIs: Selective serotonin reuptake inhibitors; NSAIDs: Nonsteroidal antiinflammatory drugs; TNF: Tumor necrosis factor; GLP-1: Glucagon-like peptide-1; HAART: Highly active antiretroviral therapy; PPI: Proton pump inhibitor; COX: Cyclooxygenase.

pain. The belt-like sudden onset pain also radiated to the back. The patients physical examination was as follows: general appearance was good, consciousness, cooperation, and orientation was normal, blood pressure: $120 / 80 \mathrm{mmHg}$, pulse: $76 \mathrm{bpm}$, temperature: $37.5^{\circ} \mathrm{C}$, abdomen had widespread tenderness but no rebound or defense. The patient was diagnosed with $C D$ two months prior and had begun budesonide/AZT treatment, but it was learned that the patient used only budesonide and used AZT for only 12 days. The patient had no history of alcohol or smoking. According to laboratory tests: WBC: $12,800 / \mathrm{mm}^{3}$, platelet: $250,000 / \mathrm{mm}^{3}$, hemoglobin: $12.4 \mathrm{~g} / \mathrm{dL}$, glucose: $105 \mathrm{mg} / \mathrm{dL}$, urea: $9 \mathrm{mg} / \mathrm{dL}$, creatinine: $0.7 \mathrm{mg} / \mathrm{dL}$, aspartate aminotransferase: $11 \mathrm{U} / \mathrm{L}$, alanine aminotransferase: $14 \mathrm{U} / \mathrm{L}$, gamma glutamyl transferase: $13 \mathrm{U} / \mathrm{L}$, alkaline phosphatase: $46 \mathrm{IU} / \mathrm{L}$, total bilirubin: $0.8 \mathrm{mg} / \mathrm{dL}$, direct bilirubin: $0.1 \mathrm{mg} / \mathrm{dL}$, amylase: $1,276 \mathrm{U} / \mathrm{L}$, lipase: 2,988 U/L, sodium: $137 \mathrm{mEq} / \mathrm{L}$, potassium: $3.9 \mathrm{mEq} / \mathrm{L}$, calcium: $9.3 \mathrm{mg} / \mathrm{dL}$, lactate dehydrogenase: $258 \mathrm{mg} / \mathrm{dL}, \mathrm{C}$-reactive protein: $5.2 \mathrm{mg} / \mathrm{dL}$. Chest X-ray was unremarkable. Abdomen ultrasound revealed thickening of the caecum-terminal ileum wall at the ileocecal valve level, changes consistent with edema-inflammation of surrounding mesenteric fatty tissue, and a few 
millimetric mesenteric lymph node. The patient with known $\mathrm{CD}$ had no pathology other than exacerbation of symptoms. The patient was hospitalized in the internal medicine inpatient service with AP diagnosis. Oral intake was stopped, AZT and budesonide were discontinued, and hydration treatment was initiated. The patient's Ranson score was calculated as 1 point. In terms of etiology, triglyceride was detected as $58 \mathrm{mg} / \mathrm{dL}$ and gallbladder stone, alcohol use, hypertriglyceridemia, and hypercalcemia were ruled out. Drug-induced acute pancreatitis was considered foremost. The fact that the patient using budesonide developed AP after starting AZT and that AZT more frequently causes AP compared to budesonide led us to believe that our case was AP induced by AZT. Blood tests performed in the $48^{\text {th }}$ hour of treatment showed amylase: $932 \mathrm{U} / \mathrm{L}$ and lipase: $1862 \mathrm{U} / \mathrm{L}$, pain regressed and there was no need to repeat abdomen tomography. On the fourth day of treatment pain had completely resolved, amylase: $168 \mathrm{U} / \mathrm{L}$, lipase: $218 \mathrm{U} / \mathrm{L}$, and $\mathrm{CRP}$ regressed to $0.8 \mathrm{mg} / \mathrm{dL}$; the patient was initiated budesonide and mesalamine by gastroenterology, discharged and called for outpatient follow-up.

\section{DISCUSSION}

Acute pancreatitis is a severe clinical condition with mortality rate varying between $1-30 \%{ }^{[6]}$ A study ${ }^{[7]}$ on the prevalence of drug-induced acute pancreatitis report rates of approximately $8 \%$, while a study from our country reported ${ }^{[8]}$ a rate of $10 \%$. In a study by Eland et al., ${ }^{[9]}$ drugs such as AZT, cimetidine, interferon-alpha, methyldopa, metronidazole, olsalazine, and oxyphenbutazone were reported to be definitely associated with AP. Later studies reported over 50 more drugs other than these that were associated with $\mathrm{AP}^{[3]}$ Although it is not known exactly how drugs cause AP, the cytotoxic effects of drugs are thought to be caused by mechanisms such as biliary construction, accumulation of toxic metabolites, and hypersensitivity. Drug-induced acute pancreatitis is diagnosed by drug provocation test. If AP reoccurs, definite diagnosis of DIAP is made. ${ }^{[10]}$

The literature reports AP risk is eight times higher in patients using AZT. ${ }^{[11]}$ Acute pancreatitis associated with AZT was first reported in 1972. ${ }^{[12]}$ AZT-induced AP is generally mild and rarely causes pancreas necrosis. ${ }^{[13]}$
Our patient was diagnosed with $\mathrm{CD}$ two months prior and was initiated AZT/budesonide, however, the patient began AZT much later. Acute pancreatitis was detected 12 days after our patient began AZT. Drug-induced acute pancreatitis diagnosis, as in other AP causes, is made by excluding other causes. ${ }^{[14]}$ Causes such as gallbladder stones, alcohol, hypertriglyceridemia, and hypercalcemia were also ruled out in our patient. ${ }^{[15]}$ The fact that the patient also using budesonide developed AP after starting AZT and that AZT more frequently causes AP compared to budesonide led us to believe that our case was AP induced by AZT.

Although azathioprine-induced AP is known to be mild, cases of severe AP and pancreas necrosis have been reported in the literature. ${ }^{[13,16]}$ Our case had a mild course in accordance with the literature and showed clinical improvement on the third day. Acute pancreatitis generally develops three to six weeks after start of AZT. ${ }^{[15]}$ In one case reported AZT-induced AP on the $10^{\text {th }}$ day. ${ }^{[17]}$ In our patient, AP was detected on the $12^{\text {th }}$ day of treatment. AZT is contraindicated in patients who develop AZT-induced AP and absolutely should not be used. ${ }^{[18]}$ In our patient budesonide/mesalamine was initiated and AP did not redevelop in follow-up.

In conclusion, it should be kept in mind that AZT frequently causes AP, patients using AZT should be cautious in terms of AP and should immediately seek medical care if they develop clinical symptoms indicative of AP.

\section{Declaration of conflicting interests}

The authors declared no conflicts of interest with respect to the authorship and/or publication of this article.

\section{Funding}

The authors received no financial support for the research and/or authorship of this article.

\section{REFERENCES}

1. Andersen DK, Biliary TR, Dunn DL, Hunter JG. Schwartz's principles of surgery. 10th ed. New York: McGraw-Hill; 2015.

2. Vidarsdottir $\mathrm{H}$, Möller $\mathrm{PH}$, Vidarsdottir $\mathrm{H}$, Thorarinsdottir H, Björnsson ES. Acute pancreatitis: a prospective study on incidence, etiology, and outcome. Eur J Gastroenterol Hepatol 2013;25:1068-75.

3. Jones MR, Hall OM, Kaye AM, Kaye AD. Druginduced acute pancreatitis: a review. Ochsner J 2015;15:45-51. 
4. Rünzi M, Layer P. Drug-associated pancreatitis: facts and fiction. Pancreas 1996;13:100-9.

5. Herrlinger KR, Stange EF. The pancreas and inflammatory bowel diseases. Int $\mathrm{J}$ Pancreatol 2000;27:171-9.

6. VanWoerkom R, Adler DG. Acute pancreatitis: review and clinical update. Hosp Physician 2009;45:9-19.

7. Mennecier D, Pons F, Arvers P, Corberand D, Sinayoko L, Harnois F, et al. Incidence and severity of non alcoholic and non biliary pancreatitis in a gastroenterology department. Gastroenterol Clin Biol 2007;31:664-7.

8. Atay AE, Yorulmaz E, Gökmen E, Güllü BE, Şit D. Antihipertansif ilaç kullanımına bağlı akut pankreatit Göztepe Tip Dergisi 2013;28:136-40.

9. Eland IA, van Puijenbroek EP, Sturkenboom MJ, Wilson JH, Stricker BH. Drug-associated acute pancreatitis: twenty-one years of spontaneous reporting in The Netherlands. Am J Gastroenterol 1999;94:2417-22.

10. Underwood TW, Frye CB. Drug-induced pancreatitis. Clin Pharm 1993;12:440-8.

11. Floyd A, Pedersen L, Nielsen GL, Thorlacius-Ussing O,
Sorensen HT. Risk of acute pancreatitis in users of azathioprine: a population-based case-control study. Am J Gastroenterol 2003;98:1305-8.

12. Nogueira JR, Freedman MA. Acute pancreatitis as a complication of Imuran therapy in regional enteritis. Gastroenterology 1972;62:1040-1.

13. Haber CJ, Meltzer SJ, Present DH, Korelitz BI. Nature and course of pancreatitis caused by 6-mercaptopurine in the treatment of inflammatory bowel disease. Gastroenterology 1986;91:982-6.

14. Kaurich T. Drug-induced acute pancreatitis. Proc (Bayl Univ Med Cent) 2008;21:77-81.

15. Mallory A, Kern F Jr. Drug-induced pancreatitis: a critical review. Gastroenterology 1980;78:813-20.

16. Venkatesh PG, Navaneethan U. Azathioprine induced pancreatitis in a patient with co-existing autoimmune pancreatitis and hepatitis. JOP 2011;12:250-4

17. Yllmaz Ş. Azatioprin ilişkili akut pankreatit: Bir olgu sunumu. Akademik Gastroenteroloji Dergisi 2012;11:87-9.

18. Sturdevant RA, Singleton JW, Deren JL, Law DH, McCleery JL. Azathioprine-related pancreatitis in patients with Crohn's disease. Gastroenterology 1979;77:883-6. 